\title{
RESPON TANAMAN TOMAT (Lycopersicum esculentum, mill), AKIBAT PEMBERIAN UREA DAN PUPUK DAUN MAMIGRO TERHADAP PERTUMBUHAN DAN HASIL TANAMAN
}

\author{
Tomato Plant Response (Lycopersicum Esculentum Mill) Due To Urea And \\ Mamigro Leaf Fertilizer On Plant Growth And Yield
}

\author{
Djarwatiningsih, Suwandi, Guniarti dan Wardani \\ Program Studi Agroteknologi, Fakultas Pertanian, UPN Veteran Jawa Timur \\ e-mail : ${ }^{1}$ email@ upnjatim.ac.id, ${ }^{2}$ suwardi@upnjatim.ac.id, ${ }^{3}$ guniarti@upnjatim.ac.id, \\ 4awrdani@upnjatim.ac.id
}

\begin{abstract}
ABSTRAK
Usaha yang dapat dilakukan untuk meningkatkan pertumbuhan dan hasil tanaman tomat dapat dilakukan melalui pemberian pupuk urea dan pupuk daun. Salah satu pupuk daun yang digunakan adalah pupuk daun mamigro. Respon tanaman akibat dari pemberian pupuk dapat meningkatkan pertumbuhan dan hasil, apabila dosis, jenis, waktu dan cara pemberian yang sesuai. Penelitian ini bertujuan untuk mengetahui respon tanaman akibat dari pemberian pupuk urea dan pupuk daun mamigro, terhadap pertumbuhan dan hasil tanaman. Penelitian ini merupakan percobaan faktorial yang disusun menggunakan Rancangan Acak Kelompok, yang terdiri dari dua faktor dan diulang tiga kali. Faktor I adalah pupuk urea $(\mathrm{N})$, terdiri dari tiga level yaitu N1 (45 kg/ha), N2 (75 kg/ha) dan N3 (105 kg/ha). Faktor II adalah pupuk daun mamigro (D), terdiri dari tiga level yaitu D1 (2,5 g/l air), D2 (5 g/l air) dan D3 (7,5 g/l air). Hasil penelitian menunjukkan bahwa kombinasi perlakuan antara pupuk urea dan pupuk daun mamigro terjadi interaksi pada umur 14, 28, 35, 42 dan 49 hari setelah tanam, terhadap parameter pengamatan mamigro tinggi tanaman, jumlah bunga pada umur 35 dan 49 hari setelah tanam, jumlah buah per tanaman dan berat buah per tanaman.
\end{abstract}

Kata Kunci : Tomat, Urea, Pupuk Daun Mamigro

\begin{abstract}
ABSTRACK
The effort to increase the growth and yields tomato plants can be done by giving Urea and leaf fertilizer. One f the leaf fertilizers is Mamigro. Response due to fertilizer can increase growth and yield if dosage, variants, time and the way how to give is appropriate.This research is aimed to know the response of tomato plant due to Urea and Mamigro leaf fertilizer to the growth and yield. This research is factorial experiment which is arranged by Completely Randomized Block Design, consist of two factors and repeated three times. The first factor is Urea $(N)$, consist of three level those are $N,(45$ $\mathrm{kg} / \mathrm{ha}), \mathrm{N} 2$ (75 kg/ha) and D1 (2,5 g/l water), D2 (5 g/l water) and D3 (7,5 g/l water).The result of the research show that treatment combination between Urea and Mamigro cause interaction at the age of 14,28, 35, 42 and 49 days after planting to the experiment parameter, plant height, number of flower at the age of 35 and 49 days after planting, number of fruit each plant and fruit weight each plant.
\end{abstract}

Key word: Tomato, Urea, Mamigro Leaffertilizer 


\section{PENDAHULUAN}

Peningkatan taraf hidup masyarakat, diikuti dengan peningkatan selera konsumsi pada sayuran dan pemilihan buah dengan kualitas yang baik. Usaha memenuhi kebutuhan akan hal tersebut dibutuhkan langkah dalam meningkatkan produktivitas tanaman.

Tomat (lycopersicum esculentum, mill) merupakan salah satu jenis sayuran buah yang banyak diusahakan dan dikonsumsi dalam skala besar dan secara komersial. Pemanfaatan buah tomat dapat memberi peluang dalam upaya pengembangan dalam usaha budidaya tanaman buah tomat.

Salah satu kendala dalam usaha budidaya tanaman tomat adalah rusaknya sifat fisik tanah, menurunnya persediaan bahan organik dalam tanah dan kesuburan tanah. Pemupukan merupakan salah satu usaha untuk memperbaiki tingkat kesuburan tanah, sehingga tanaman dapat tumbuh dengan baik dan menghasilkan produksi yang tinggi. Penggunaan pupuk sangat mempengaruhi sifat fisik, kimia dan biologi tanah, terutama penggunaan bahan organik dapat memberikan unsur hara bagi tanaman (Sigito, 1995).

Nitrogen merupakan salah satu unsur penting bagi tanaman untuk mendapatkan hasil yang maksimal dan unsur yang dibutuhkan oleh tanaman dalam jumlah yang besar. Namun, seringkali akibat teknik aplikasi nitrogen yang salah menyebabkan terjadinya leaching, aliran permukaan (run off), penguapan dan denitrifikasi. Usaha mengurangi dampak negatif perlu dilakukan efisiensi penggunaan nitrogen. Cara ini secara ekonomis sangat menguntungkan, karena mengurangi penggunaan pupuk nitrogen. Pupuk nitrogen mengandung hara tanaman $\mathrm{N}$. Bentuk senyawa $\mathrm{N}$ pada umumnya berupa nitrat, amonium, amina dan sianida. Bentuk pupuk $\mathrm{N}$ dapat berupa kristal, prill, pellet, tablet maupun cair (Rosmarkan dan Yuwono, 2002). Ada 17 jenis unsur yang dibutuhkan tanaman. Nitrogen merupakan unsur yang sangat penting serta paling banyak mendapatkan perhatian. Di dalam tanaman, nitrogen berfungsi sebagai penyusun protein, serta membantu pertumbuhan vegetatif tanaman. Unsur hara makro dapat disuplai dari pupuk kandang, urea, pupuk ZA dan dari berbagai jenis pupuk daun (Wiyanta, 2004).

Pupuk daun mamigro merupakan pupuk daun majemuk, berbentuk tepung halus yang larut dalam air lebih cepat dengan hasil larutan yang sempurna. Kegunaan pupuk daun mamigro untuk mempercepat pertumbuhan dan perkembangan jaringan tanaman. Daun lebih subur dan meningkatkan kualitas hasil. Kandungan kadar N 21\%, $\mathrm{P}_{2} \mathrm{O}_{5} 21 \%$, $\mathrm{K}_{2} \mathrm{O} 21 \%$ dan unsur hara mikro yang melengkapi yaitu $\mathrm{Ca}, \mathrm{S}, \mathrm{Mn}, \mathrm{Zn}, \mathrm{Fe}, \mathrm{Cu}, \mathrm{B}$, Mo dan Co. Warna pupuk putih konsentrasi normal yang dianjurkan adalah 2,5-5 g dalam satu liter air (Anonymous, 1992).

\section{BAHAN DAN METODE}

Penelitian dilakukan pada lahan tegalan di Dusun Klinter Desa Pelem Kecamatan Kertosono Kabupaten Nganjuk. Ketinggian $+46 \mathrm{~m}$ di atas permukaan laut.

Bahan yang digunakan adalah benih tomat varietas Donna, pupuk kandang, pupuk urea, pupuk SP-36, pupuk $\mathrm{KCl}$, pupuk daun mamigro, insektisida marshal, buldox, furadan $3 \mathrm{G}$ dan fungisidan dithane dan beulate.

Alat yang digunakan adalah cangkul, ajir, tali rafia, hand sprayer, meteran, cetok, ember, gembor, mulsa plastik, timbangan, timbangan analitik, dan alat tulis. 
Percobaan ini merupakan percobaan faktorial yang disusun secara rancangan acak kelompok (RAK) dengan dua faktor dan diulang sebanyak tiga kali. Faktor pertama adalah pupuk urea $(\mathrm{N})$, yag meliputi tiga level, yaitu ; $\mathrm{N}=45 \mathrm{~kg} / \mathrm{ha}, \mathrm{N} 2=75 \mathrm{~kg} / \mathrm{ha}$ dan $\mathrm{N} 3=105 \mathrm{~kg} / \mathrm{ha}$. Faktor kedua adalah dosis pupuk daun mamigro (D), yang meliputi tiga level, yaitu ; D1 = 2,5 g/l air, D2 = $5 \mathrm{~g} / 1$ air dan D3 = 7,5 g/l air.

Pelaksanaan percobaan meliputi; pembibitan, persiapan lahan, penanaman yang meliputi; penyulaman, pengairan, pemberian ajir, pemupukan, pemberantasan hama dan penyakit, pengamatan, panen dan pasca panen.

\section{HASIL DAN PEMBAHASAN}

\section{Tinggi Tanaman $(\mathbf{c m})$}

Hasil analisi ragam menunjukkan bahwa pengamatan tinggi tanaman tomat pada umur 21 HST (hari setelah tanam) dan pada umur 56 HST (hari setelah tanam), akibat dari perlakuan pemberian pupuk urea $(\mathrm{N})$ dengan pupuk daun mamigro (D), terjadi perbedaan yang sangat nyata pada uji beda nyata terkecil (BNT 5\%). Tabel 1, pada pemberian pupuk urea $75 \mathrm{~kg} / \mathrm{ha}(\mathrm{N} 2)$ dan pemberian pupuk daun mamigro (D) pada perlakuan $5 \mathrm{~g} / \mathrm{l}$ air (D2), tetapi tidak berbeda nyata dengan perlakuan $2,5 \mathrm{~g} / \mathrm{l}$ air (D1).

Pada Tabel 1, perlakuan pemberian pupuk urea (N2) sebanyak $75 \mathrm{~kg} / \mathrm{ha}$, berpengaruh baik terhadap pertumbuhan tinggi tanaman. Hal ini disebabkan karena pupuk yang diberikan segera terurai di dalam tanah dan tersedia oleh tanah. Pupuk dalam jumlah tersebut yaitu $75 \mathrm{~kg} / \mathrm{ha}$ dinilai sudah cukup untuk memacu pertumbuhan tinggi tanaman, karena penyerapan unsur hara dapat berlangsung dengan baik. Lebih lanjut Lingga (2004) menyebutkan bahwa jumlah unsur $\mathrm{N}$ yang cukup di dalam tanah untuk memacu pertumbuhan vegetatif tanaman, terutama pertumbuhan tinggi tanaman, jika jumlah $\mathrm{N}$ di dalam tanah berlebih air, maka pada kondisi tertentu akan mengganggu siklus tanaman.

Tabel 1. Tinggi Tanama Tomat $(\mathrm{cm})$ pada Perlakuan Pemberian Pupuk Urea $(\mathrm{N})$ dengan Pupuk Daun Mamigro (D), pada Umur 21 dan 56 HST (Hari Setelah Tanam).

\begin{tabular}{lcc}
\hline \multicolumn{1}{c}{ Perlakuan } & \multicolumn{2}{c}{ Umur Pengamatan (HST) } \\
\cline { 2 - 3 } & 21 & 56 \\
\hline Pupuk Urea & $23,89 \mathrm{~b}$ & $89,59 \mathrm{~b}$ \\
$\mathrm{~N} 1=45 \mathrm{~kg} / \mathrm{ha}$ & $27,57 \mathrm{c}$ & $94,96 \mathrm{c}$ \\
$\mathrm{N} 2=75 \mathrm{~kg} / \mathrm{ha}$ & $19,99 \mathrm{a}$ & $85,06 \mathrm{a}$ \\
$\mathrm{N} 3=105 \mathrm{~kg} / \mathrm{ha}$ & 1,74 & 3,29 \\
\hline BNT 5\% & & \\
Pupuk Daun Mamigro & $25,05 \mathrm{~b}$ & $91,87 \mathrm{~b}$ \\
$\mathrm{D} 1=2,5 \mathrm{~g} / \mathrm{l}$ air & $25,28 \mathrm{~b}$ & $92,02 \mathrm{~b}$ \\
$\mathrm{D} 2=5,0 \mathrm{~g} / \mathrm{l}$ air & $21,12 \mathrm{a}$ & $3,72 \mathrm{a}$ \\
$\mathrm{D} 3=7,5 \mathrm{~g} / \mathrm{l}$ air & 1,74 & 3,29 \\
\hline BNT 5\% & \multicolumn{2}{c}{}
\end{tabular}




\section{Jumlah Bunga Per Tanaman}

Hasil analisis ragam pada parameter pengamatan jumlah bunga per tanaman pada umur 35 dan 49 HST, menunjukkan adanya interaksi akibat dari perlakuan anatara pupuk urea dan pupuk daun mamigro. Terjadi perbedaan yang nyata pada uji beda nyata terkecil (BNT 5\%).

Tabel 2. Interaksi Jumlah Bunga Per Tanaman pada Umur 35 dan 49 HST, Akibat dari Perlakuan Pemberian Antara Pupuk Urea dan Pupuk Daun Mamigro.

\begin{tabular}{|c|c|c|c|c|}
\hline \multirow{2}{*}{ Perlakuan } & \multicolumn{4}{|c|}{ Umur Pengamatan (HST) } \\
\hline & \multicolumn{2}{|c|}{35} & \multicolumn{2}{|l|}{49} \\
\hline N1D1 & 7,89 & $\mathrm{~cd}$ & 16,00 & $\mathrm{~cd}$ \\
\hline N1D2 & 9,33 & $\mathrm{~d}$ & 20,66 & $\mathrm{e}$ \\
\hline N1D3 & 7,11 & $\mathrm{~b}$ & 12,11 & $\mathrm{~b}$ \\
\hline N2D1 & 11,22 & $\mathrm{e}$ & 24,83 & $\mathrm{f}$ \\
\hline $\mathrm{N} 2 \mathrm{D} 2$ & 12,55 & $\mathrm{e}$ & 28,55 & $\mathrm{~g}$ \\
\hline N2D3 & 8,44 & $\mathrm{~cd}$ & 17,67 & de \\
\hline N3D1 & 7,55 & $\mathrm{c}$ & 11,00 & $\mathrm{ab}$ \\
\hline N3D2 & 5,78 & $\mathrm{ab}$ & 14,00 & bc \\
\hline N3D3 & 4,78 & $\mathrm{a}$ & 7,78 & $\mathrm{a}$ \\
\hline & \multicolumn{2}{|c|}{1,71} & \multicolumn{2}{|c|}{3,43} \\
\hline
\end{tabular}

Keterangan: Angka-angka yang didampingi huruf yang sama pada kolom yang sama tidak berbeda nyata pada uji BNT $(\mathrm{P}=0,05)$

Pada Tabel 2, menunjukkan bahwa parameter pengamatan jumlah bunga per tanaman terbanyak dicapai pada perlakuan kombinasi antara pemberian pupuk urea 75 $\mathrm{kg} / \mathrm{ha}$ dengan pupuk daun mamigro $5 \mathrm{~g} / \mathrm{l}$ air (N2D2), tetapi tidak berbeda nyata dengan perlakuan N2D1 yaitu pemberian pupuk urea $75 \mathrm{~kg} / \mathrm{ha}$ dengan pupuk daun mamigro 2,5 g/l air, pada umur 35 HST. Pada umur 49 HST pengamatan jumlah bunga per tanaman terbanyak dicapai pada perlakuan kombinasi antara pemberian pupuk urea $75 \mathrm{~kg} / \mathrm{ha}$ dengan pupuk daun mamigro $5 \mathrm{~g} / \mathrm{l}$ air yaitu perlakuan N2D2. Pada pengamatan umur 35 HST jumlah bunga per tanaman paling sedikit pada perlakuan kombinasi N3D3 yaitu 105 $\mathrm{kg} / \mathrm{ha}$ pupuk urea dengan pupuk daun mamigro 7,5 g/l air, tetapi tidak berbeda nyata dengan perlakuan N3D2 dan N1D3. Pada pengamatan jumlah bunga pada umur 49 HST, jumlah bunga per tanaman yang paling sedikit pada perlakuan N3D3, tetapi tidak berbeda nyata dengan perlakuan N3D1 dan N1D3. Pemberian pupuk urea dengan pupuk daun mamigro pada parameter jumlah bunga per tanaman pada kombinasi perlakuan saat tanaman berumur 35 HST dan 49 HST diduga lebih kuat, sebab pupuk yang diberikan sudah dalam jumlah yang cukup, sehingga penyerapan unsur hara yang terjadi pada proses pertumbuhan dan perkembangan tanaman dapat merangsang dan mendorong keluarnya bunga lebih banyak.

Lebih lanjut Gardner, et all (1991) menyatakan bahwa daun merupakan sumber N untuk pembentukan bunga, yaitu dengan cara mobilisasi unsur $\mathrm{N}$ yang ada pada daun. Suplai unsur $\mathrm{N}$ yang cukup akan membantu dalam penyerapan dan pemanfaatan cahaya matahari yang diterima oleh daun yang lebih besar diduga dapat mendorong terbentuknya unsur karbohidrat lebih banyak dan pada fase reproduktif akan dipergunakan oleh tanaman dalam proses pembentukan bunga. 


\section{Jumlah Buah Per Tanaman}

Hasil analisis ragam jumlah buah per tanaman menunjukkan interaksi perlakuan antara pemberian pupuk urea dan pupuk daun mamigro. Terjadi perbedaan yang nyata pada uji beda nyata terkecil (BNT 55), pada Tabel 3.

Tabel 3. Interaksi Jumlah Buah Per Tanaman, Akibat dari Perlakuan Pemberian Antara Pupuk Urea dan Pupuk Daun Mamigro

\begin{tabular}{|c|c|c|c|}
\hline Perlakuan & D1 & $\mathrm{D} 2$ & D3 \\
\hline N1 & $37,67 \mathrm{bc}$ & $41,17 \mathrm{~cd}$ & $34,00 \mathrm{~b}$ \\
\hline $\mathrm{N} 2$ & $45,17 \mathrm{~d}$ & $53,33 \mathrm{e}$ & $40,00 \mathrm{c}$ \\
\hline N3 & $36,67 \mathrm{bc}$ & $28,33 \mathrm{a}$ & $24,00 \mathrm{a}$ \\
\hline
\end{tabular}

BNT 5\% $(\mathrm{P}=0,05)$.

Tabel 3 menunjukkan bahwa pada pengamatan parameter jumlah buah per tanaman, buah terendah pada N3D3 sebesar 24 buah per tanaman, tetapi tidak berbeda nyata pada uji beda terkecil (BNT 5\%) dengan kombinasi perlakuan N3D2 yaitu perlakuan kombinasi antara pemberian pupuk urea $105 \mathrm{~kg} / \mathrm{ha}$ dengan pupuk daun mamigro $5 \mathrm{~g} / \mathrm{l}$ air.

Perlakuan kombinasi antara pemberian pupuk urea $75 \mathrm{~kg} / \mathrm{ha}$ dengan pupuk daun mamigro $5 \mathrm{~g} / \mathrm{l}$ air (N2D2), memberikan hasil jumlah buah per tanaman tertinggi yaitu sebesar 53,33 buah. Hal ini diduga berhubungan dengan banyaknya jumlah daun. Semakin banyak jumlah daun cenderung semakin meningkatkan laju penyerapan sinar matahari sehingga dapat meningkatkan jumlah fotosintat yang dihasilkan oleh daun (Ross dan Salisbury, 1995). Daun merupakan sumber nitrogen yang berfungsi untuk merangsang pembentukan bunga dengan cara memobilisasi unsur $\mathrm{N}$ yang ada pada daun, selanjutnya didistribusikan ke bunga dan buah.

\section{Berat Buah Per Tanaman}

Hasil analisis ragam berat buah per tanaman menunjukkan interaksi dari perlakuan antara pemberian pupuk urea dan pupuk daun mamigro. Terjadi perbedaan yang nyata pada uji beda nyata terkecil (BNT 5\%), pada Tabel 4.

Tabel 4. Interaksi Berat Buah Per Tanaman (Kg/Tanaman), Akibat dari Perlakuan Pemberian antara Pupuk Urea dan Pupuk Daun Mamigro.

\begin{tabular}{lccc}
\hline \multicolumn{1}{c}{ Perlakuan } & D1 & D2 & D3 \\
\hline \multirow{N}{*}{ N } & $2,81 \mathrm{~cd}$ & $3,27 \mathrm{e}$ & $2,59 \mathrm{bc}$ \\
$\mathrm{N} 2$ & $3,38 \mathrm{ef}$ & $3,58 \mathrm{f}$ & $3,03 \mathrm{~d}$ \\
$\mathrm{~N} 3$ & $2,65 \mathrm{bc}$ & $2,51 \mathrm{~b}$ & $2,14 \mathrm{a}$ \\
\hline BNT 5\% & \multicolumn{3}{l}{0,23} \\
\hline Keterangan : & Angka-angka yang didampingi huruf yang sama tidak berbeda nyata pada uji \\
& BNT $(\mathrm{P}=0,05)$ &
\end{tabular}

Pada Tabel 4, menunjukkan bahwa berat buah terendah terdapat pada perlakuan kombinasi N3D3. Sedangkan hasil terbesar yaitu pada perlakuan kombinasi N2D2, tidak berbeda dengan perlakuan N2D1, namun berbeda dengan pelakuan lainnya. Hal ini diduga bahwa pemberian pupuk urea dan pupuk daun mamigro lebih tepat dosis, sebab dosis pupuk urea yang diberikan dalam jumlah cukup, sehingga penyerapan unsur hara 
dalam tubuh tanaman diduga dapat optimal dan proses metabolisme yang terjadi digunakan dalam pembentukan bahan makanan dan kualitas buah meningkat, mengakibatkan peningkatan berat buah. Lebih lanjut Samsudin (2005) menyatakan bahwa penyediaan unsur $\mathrm{N}$ dalam jumlah yang cukup didalam tubuh tanaman akan mendorong keluarnya bunga pada tanaman lebih banyak. Unsur $\mathrm{N}$ sangat diperlukan oleh tanaman pada fase vegetatif yaitu untuk memperbanyak daun dan fase generatif membantu pada proses pembentukan bunga, mencegah kerontokan bunga dan memperbaiki serta meningkatkan kualitas hasil buah.

\section{KESIMPULAN}

Hasil penelitian pemberian pupuk urea dan pupuk daun mamigro, terhadap pertumbuhan dan hasil tanaman tomat dapat disimpulkan bahwa :

1. Perlakuan kombinasi antara pupuk urea dan pupuk daun mamigro terjadi interaksi yang nyata terhadap jumlah bunga per tanaman umur 35 dan 49 HST, jumlah buah per tanaman dan berat buah per tanaman.

2. Perlakuan pemberian pupuk urea berpengaruh nyata terhadap pengamatan parameter tinggi tanaman pada umur 21 dan 56 HST yaitu pemberian sebesar $75 \mathrm{~kg} / \mathrm{ha}$.

3. Perlakuan pemberian pupuk daun mamigro berpengaruh nyata terhadap pengamatan parameter tinggi tanaman pada umur $21 \mathrm{HST}$ yaitu D2 $=5,0 \mathrm{~g} / \mathrm{l}$ dan $\mathrm{D} 1=2,5 \mathrm{~g} / \mathrm{l}$ air dan pada umur 56 HST.

\section{DAFTAR PUSTAKA}

PT.Tanindo Subur Prima. 1992. Brosur Pupuk daun Mamigro. Sidoarjo, 1-5.

Gardner, Pearce dan Michell. 1991, Fisiologi Tanaman Budidaya. Universitas Indonesia Press. Jakarta, 428 hal.

Lingga. 2004. Petunjuk Penggunaan Pupuk. Edisi Revisi Penebar Swadaya. Jakarta. 163 hal.

Rosmarkan, A dan Yuwono, N.W. 2002. Ilmu Kesuburan Tanah. Kanisius. Yogyakarta. 216 hal.

Ross, C.W dan Salisbury F.B.1995. Fisiologi Tumbuhan Jilid 1. ITB Bandung. 241 hal.

Samsudin. 2005. Bertanam Cabe. Bina Cipta. Jakarta. 38 hal.

Sugito, Y. 1995. Dasar Agronomi. Fakultas Pertanian. Universitas Brawijaya Malang. 61 hal.

Wijayatna, M.F. 2004. Potensi Indonesia Sebagai Penghasil Guano Fosfat Kelelawar (1). http://rudyct.tripod.com/seml023/mfatah.htm. Diakses tanggal 4 Desember 2004. 